\title{
COLLEGE ENTRANCE REQUIREMENTS IN ENGLISH
}

College entrance requirements in English are now practically uniform the country over. The committee has to consider merely the possibility of securing a better uniformity and a more satisfactory course of study. The necessity of correlating college preparatory courses of study in most schools with those courses that are not intended to fit for college will ultimately force a consideration of these problems with reference to every subject of the curriculum.

With a view to learning the consensus of opinion as to the practical workings of the present scheme, the four associations of colleges and preparatory schools, representing respectively the New England states, the Middle states and Maryland, the North Central states, and the Southern states, sent out in January the following circular of inquiry to the leading schoolmasters and teachers of English in the secondary schools and colleges:

CIRCULAR OF INQUIRY NO. I

I. Is the requirement for reading satisfactory? If not, what specific objection have you to make?

2. Is the requirement for study satisfactory? If not, what specific objection have you to make?

3. How many years of study do you consider necessary to fill properly the requirement as it now stands?

4. Should the requirement for reading be made a subject for a preliminary examination, so that the last year may be devoted to the books for study?

5. In your opinion should more or less than two books in the list for reading, and one book in the list for study, be changed each year?

6. In the list of books for I 898, I 899, and I900, do you find a sufficient number of books for the second and third years before entrance to college? 
7. Can you suggest three or four books, not in the above list, suitable for: $(a)$ the first year, $(b)$ the second year, $(c)$ the third year, before entrance to college? Which of such books do you recommend for reading, and which for study?

8. In the selection of books for I 898, I 899, and I900, three principles were regarded: $(a)$ that certain distinct periods and types of literature should be represented; $(b)$ that historical sequence should be considered; $(c)$ that about equal representation should be given to prose and poetry.

Should these principles continue to govern? If not, what specific objection have you to offer? What principles will you suggest in addition to, or in place of the principles here laid down?

9. Please mark with a cross the books in the following list that you have found desirable, with a double cross those that you have found especially desirable, with a circle those that you have found unsatisfactory, and with a double circle those that you have found especially unsatisfactory.

[Here follows a list of forty-four books that have been prescribed for college entrance.]

The replies to this circular from the North Central states have been tabulated by Professor F. N. Scott of the University of Michigan; those from the other districts by Mr. Wilson Farrand of the Newark Academy, Newark, N. J. Mr. Farrand (to whom the national committee is deeply indebted for many favors) furnishes the accompanying summary of replies. His recommendations to the conference, which meets in New York City, May $3 \mathrm{I}$ and June $\mathrm{I}$, for the purpose of selecting lists of books for the years following I900, are also given herewith. 
SUMMARY OF REPLIES TO CIRCULAR OF INQUIRY NO. I

\begin{tabular}{|c|c|c|c|c|c|c|}
\hline & Number of Replies & $\begin{array}{c}\text { Middle } \\
\text { States } \\
98\end{array}$ & $\begin{array}{c}\text { New } \\
\text { England } \\
\text { States } \\
x 21\end{array}$ & $\begin{array}{c}\text { Sou thern } \\
\text { States } \\
\text { xo }\end{array}$ & $\begin{array}{l}\text { North } \\
\text { Central } \\
\text { States } \\
7 x\end{array}$ & $\begin{array}{c}\text { Total } \\
300\end{array}$ \\
\hline \multirow[t]{2}{*}{ I } & Yes $\ldots \ldots \ldots \ldots \ldots$ & 72 & 59 & 7 & 42 & 180 \\
\hline & No.. $\ldots \ldots \ldots \ldots \ldots$ & I 3 & 38 & 2 & 29 & 82 \\
\hline \multirow[t]{2}{*}{2} & Yes.............. & 75 & 63 & 9 & 46 & I 93 \\
\hline & No.. $\ldots \ldots \ldots \ldots \ldots$ & 9 & 24 & I & 23 & 57 \\
\hline \multirow[t]{4}{*}{3} & I Year........... & 7 & I 2 & & 3 & 22 \\
\hline & 2 Years $\ldots \ldots \ldots \ldots$ & 25 & 44 & I & I9 & 89 \\
\hline & 3 Years. . . . . . . . & 37 & 26 & 2 & I 3 & 78 \\
\hline & 4 Years...$\ldots \ldots \ldots$ & I3 & I 5 & 4 & 34 & 66 \\
\hline \multirow[t]{2}{*}{4} & Yes.............. & 46 & 62 & 2 & 24 & I34 \\
\hline & No........... & 34 & 45 & 5 & 40 & I 24 \\
\hline \multirow[t]{3}{*}{5} & 2 and $1 \ldots \ldots \ldots \ldots$ & 44 & 44 & 5 & $4 \mathrm{I}$ & I34 \\
\hline & More $\ldots \ldots \ldots \ldots \ldots$ & I3 & I3 & 2 & I9 & 47 \\
\hline & $\begin{array}{l}\text { Less }, \ldots \ldots \ldots \ldots \ldots \\
\text { "No }{ }^{\prime} \ldots \ldots \ldots \ldots\end{array}$ & $\begin{array}{l}\text { I3 } \\
\text { "8", }\end{array}$ & $\begin{array}{r}3 I \\
8\end{array}$ & I & 5 & $\begin{array}{l}50 \\
\text { I } 6\end{array}$ \\
\hline \multirow[t]{2}{*}{6} & Yes................ & 62 & 55 & 3 & 38 & 158 \\
\hline & No $\ldots \ldots \ldots \ldots \ldots \ldots$ & I6 & 25 & 2 & 24 & 67 \\
\hline \multirow[t]{7}{*}{8} & Yes.............. & 53 & 49 & 2 & 50 & I 54 \\
\hline & $\mathrm{b}=0 \ldots \ldots \ldots \ldots \ldots$ & 4 & I I & I & 7 & 23 \\
\hline & $a+b=0 \ldots \ldots \ldots \ldots$ & 3 & I & & 2 & 6 \\
\hline & Interest. . . . . . . . & 3 & I I & I & 2 & I 7 \\
\hline & Pupil. $\ldots \ldots \ldots \ldots \ldots$ & 8 & IO & I & 2 & $2 \mathrm{I}$ \\
\hline & More Prose $\ldots \ldots \ldots$ & & 5 & I & & 6 \\
\hline & More Poetry......... & 2 & 3 & & & 5 \\
\hline
\end{tabular}

Note. - In replies to No. I and No. 2 objections to specific books have been ignored, as covered by No. 9. Twenty-three object to reading list as too long or too difficult ; twenty as too uninteresting ; nine as containing too little American literature ; other objections, scattering. Substantially the same objections are made to the study list.

In replies to No. 8, "Interest" means "Intrinsic interest and worth of books should be considered." "Pupil" means, "Adaptability to pupils should be considered."

This content downloaded from 128.143.023.241 on August 11, 2016 05:30:16 AM All use subject to University of Chicago Press Terms and Conditions (http://www.journals.uchicago.edu/t-and-c). 
SUMMARY OF REPLIES TO 9

\begin{tabular}{|c|c|c|c|c|}
\hline & $x$ & $\mathbf{x x}$ & o & oo \\
\hline$\ldots \ldots \ldots \ldots \ldots$ & 94 & 12 & 20 & 3 \\
\hline$\ldots \ldots \ldots \ldots \ldots \ldots \ldots \ldots$ & 87 & 39 & 27 & 9 \\
\hline$\ldots \ldots \ldots, \ldots, \ldots, \ldots, \ldots$ & I 2 I & 83 & 8 & 6 \\
\hline As You Like It $\ldots \ldots \ldots \ldots \ldots \ldots \ldots$ & 98 & II & 6 & 2 \\
\hline$\ldots \ldots \ldots \ldots \ldots \ldots \ldots$ & 92 & 56 & 44 & 6 \\
\hline Courtship of Miles Standish $\ldots \ldots \ldots \ldots \ldots \ldots \ldots$ & II 6 & 88 & 8 & \\
\hline David Copperfield $\ldots \ldots \ldots \ldots \ldots \ldots \ldots \ldots \ldots \ldots$ & 96 & 53 & $2 \mathrm{I}$ & 3 \\
\hline$\ldots \ldots \ldots \ldots \ldots \ldots \ldots \ldots$ & 86 & $4 \mathrm{I}$ & 19 & 4 \\
\hline Essays on Milton and Addison $\ldots \ldots \ldots \ldots \ldots \ldots$ & 100 & 65 & 24 & 4 \\
\hline Evangeline $\ldots \ldots \ldots \ldots \ldots \ldots \ldots \ldots \ldots \ldots$ & II 7 & 122 & 5 & \\
\hline First Bunker Hill Oration. $\ldots \ldots \ldots \ldots \ldots \ldots \ldots$ & 105 & 104 & 9 & I \\
\hline Flight of a Tartar Tribe $\ldots \ldots \ldots \ldots \ldots \ldots \ldots \ldots$ & 55 & 13 & 26 & I 2 \\
\hline History of the Plague $\ldots \ldots \ldots \ldots \ldots \ldots \ldots \ldots \ldots$ & $3 I$ & 6 & 55 & I 23 \\
\hline House of the Seven Gables.................... & 105 & 77 & I3 & 4 \\
\hline Pope's Iliad.$\ldots \ldots \ldots \ldots \ldots \ldots \ldots \ldots \ldots \ldots \ldots$ & 57 & 30 & 31 & 23 \\
\hline Il Penseroso $\ldots \ldots \ldots \ldots \ldots \ldots \ldots \ldots \ldots \ldots \ldots$ & I05 & 80 & 29 & 8 \\
\hline 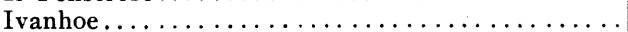 & 86 & I 26 & 5 & \\
\hline$\ldots \ldots \ldots \ldots \ldots$ & 76 & I 7 I & I & \\
\hline 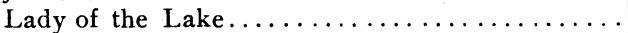 & I 30 & IO3 & 2 & \\
\hline L'Allegro $\ldots \ldots \ldots \ldots \ldots \ldots \ldots \ldots \ldots \ldots \ldots$ & 99 & 85 & 28 & 8 \\
\hline Last of the Mohicans $\ldots \ldots \ldots \ldots \ldots \ldots \ldots \ldots$ & 72 & 34 & 29 & 5 \\
\hline Life of Nelson $\ldots \ldots \ldots \ldots \ldots \ldots \ldots \ldots$ & 67 & I 2 & 25 & I3 \\
\hline Life of Samuel Johnson.................... & 89 & 55 & 18 & 4 \\
\hline 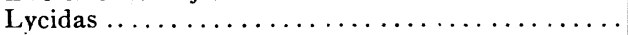 & 73 & 45 & 52 & I 3 \\
\hline 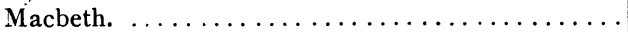 & 88 & 106 & Io & 2 \\
\hline . $\ldots \ldots \ldots \ldots \ldots, \ldots, \ldots$ & II 3 & 82 & I 2 & \\
\hline Merchant of Venice................... & 50 & 217 & & \\
\hline Midsummer Night's Dream $\ldots \ldots \ldots \ldots \ldots \ldots \ldots$ & II 3 & $6 \mathrm{I}$ & 16 & I \\
\hline Palamon and Arcite................. & 30 & 3 & 38 & 19 \\
\hline Paradise Lost, Books I and II . . . . . . . . & $8 \mathrm{I}$ & 53 & 25 & I 8 \\
\hline Princess $\ldots \ldots \ldots \ldots \ldots \ldots \ldots \ldots \ldots \ldots \ldots$ & 80 & 63 & 22 & 4 \\
\hline Second Essay on Chatham............. & 74 & 20 & 46 & 8 \\
\hline Sketch Book $\ldots \ldots \ldots \ldots \ldots \ldots \ldots \ldots$ & IIO & I30 & 6 & \\
\hline Silas Marner....... & 9I & I 28 & I I & 2 \\
\hline Sir Roger de Coverley Papers ........... & 99 & 107 & I6 & I \\
\hline Sohrab and Rustum $\ldots \ldots \ldots \ldots \ldots \ldots$ & $8 \mathrm{I}$ & 50 & 25 & 8 \\
\hline Conciliation with America $\ldots \ldots \ldots \ldots \ldots \ldots$ & 94 & 76 & 19 & 6 \\
\hline Tales of a Traveller....... & II 3 & 48 & 22 & 8 \\
\hline Twelfth Night & 94 & 43 & 24 & 2 \\
\hline Twice-Told Tales . & 97 & 75 & 18 & I \\
\hline Vicar of Wakefield.. & 92 & 65 & 3I & 7 \\
\hline Vision of Sir Launfal. & 85 & I 36 & 5 & \\
\hline Woodstock ......... & 102 & 29 & $2 \mathrm{I}$ & 7 \\
\hline
\end{tabular}

\section{BOOKS SUGGESTED IN REPLY TO QUESTION 7}

The entire list contains more than 200 works. Only those that were named by at least four persons are given below. The figures show the number of persons naming each book. Books included in the list given under No. 9 are omitted here; also 
such works as "Snow Bound," "Lady of the Lake," "Sketch Book," etc., ruled out by the last conference as usually read in the lower grades. Owing to a misunderstanding the returns on this question from the North Central states are not included in this list:

\begin{tabular}{|c|c|c|c|c|c|c|}
\hline Burroughs, & Essays, & & & & & \\
\hline Bunyan, & Pilgrim's Progress, & & - & & - & \\
\hline Byron, & Childe Harold, & - & & - & & \\
\hline Carlyle, & Heroes and Hero $W$ & orsh & nip, & & - & \\
\hline Chaucer, & Prologue, & - & & - & & \\
\hline ens, & Tale of Two Cities, & & - & & - & \\
\hline Eliot, & Romola, & - & & & & \\
\hline “ & Mill on the Floss, & & - & & - & \\
\hline Emerson, & Essays (selected), & - & & & & \\
\hline Frar & Autobiography, - & & - & & 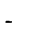 & \\
\hline Goldsmith, & Deserted Village, & - & & & & \\
\hline Gray, & Elegy, - & & - & & - & \\
\hline Holmes, & Autocrat, & - & & & & \\
\hline Hughes, & Tom Brown at Rugh & & - & & - & \\
\hline Irving, & Alhambra, & & & - & & - \\
\hline Kingsley, & Westward Ho, - & & - & & - & \\
\hline Lamb, & Essays of Elia, & - & & & & - \\
\hline Macaulay, & Clive, - & & - & & - & \\
\hline “ & Warren Hastings, & - & & - & & \\
\hline “ & Lays of Ancient Ron & me, & - & & - & \\
\hline Pope, & Rape of the Lock, & - & & - & & \\
\hline Ruskin, & Sesame and Lilies, & & - & & - & \\
\hline Shakespeare, & Hamlet, & - & & 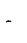 & & - \\
\hline Spenser, & Faërie Queene (part & & - & & - & \\
\hline Swift, & Gulliver's Travels, & - & & - & & \\
\hline Scott, & Kenilworth, & & - & & - & \\
\hline “ & Talisman, - & - & & - & & - \\
\hline Stevenson, & Treasure Island, & & - & & - & \\
\hline Tennyson, & Elaine, & - & & - & & - \\
\hline - & Idylls, - - & & - & & - & \\
\hline Thackeray, & Henry Esmond, & - & & - & & - \\
\hline
\end{tabular}

Owing to the difficulty of reducing many of the answers to categorical form such a summary can be at best only an approximation. It is, however, believed to be substantially accurate.

A careful study of the full replies discloses several points that seem worthy of the consideration of the conference: 
I. While a decided majority of the replies approve of the policy heretofore followed of a slight yearly change in the lists, very vigorous objection to such change is made in certain quarters. The objections come mainly from the regents of the University of the State of New York, and from representatives of the smaller high schools where the free text-book system is in force. It appears to be based chiefly on the ground of expense.

2. There is more vigorous objection than appears in the summary to certain books as lacking in intrinsic interest and in adaptability to pupils of school age. There seems to be a feeling that these two principles have not been clearly enough recognized in the past.

3. There appears to be considerable uncertainty and variety of opinion as to what is meant by the words "reading" and "study," $i$. $e$, as to how the books are to be studied, and as to what is implied by a knowledge of "subject-matter, form, and structure." It is the impression of the reviewer that if the conference will formulate a brief statement indicating what in its judgment is a reasonable standard of fulfillment of the requirement, it will be most warmly received by the schools.

The principal criticisms of the requirement as it now stands seem to be included under these three heads. ${ }^{x}$

Through the kindness of the committees of the four district associations the following circular was sent out along with the one above mentioned:

\section{CIRCULAR OF INQUIRY NO. 2}

What should be the main objects of teaching English in the secondary schools?

2. Should the subject be treated differently for pupils who are going to college, for those who are going to a scientific school, and for those who, presumably, are going to neither?

3. Should college entrance requirements determine the course in English, especially in the public high school?

4. Wherein do the present requirements for college entrance interfere with the ideal high-school course?

5. Should the formal study of English be pursued in the secondary school by all classes during the entire course? How

${ }^{\Upsilon}$ From Mr. Farrand's recommendations to the English Conference. 
many hours a week? What proportion of the time should be given to "language" and "literature" respectively?

6. What principle should determine the arrangement of books in the course?

7. Please indicate the order, by years, in which you prefer to take up the books now prescribed for college entrance. work?

8. How many books (or pages) should be set for each year's

9. Should some books be prescribed for reading and practice, and others for intensive study? What principles should be regarded in the selection of the latter?

Io. Should the practice in composition be based mainly on the books of the course?

I I. Are exercises in $(a)$ paraphrasing of poetry, $(b)$ condensation, $(c)$ correction of bad English, etc., to be recommended?

I2. Is formal study of the history of the English language and literature in the secondary school desirable?

I3. Should rhetoric be a separate study? In what year? How many hours a week?

I4. Should formal grammar be a separate study? In what year? How many hours a week?

I 5. Should secondary schools be encouraged to offer courses in Anglo Saxon and early English?

My main purpose in putting these questions was to ascertain, so far as possible, the adaptability of the present scheme to the ideal high-school course of study in English, regardless of the demands of the colleges. The answers to questions 4, 6, 7 and 8 cannot be tabulated; some others, notably $\mathrm{I}$ and 2 , do not lend themselves readily to arithmetical treatment, but I give the leading items. I hope, however, that the subsequent explanations will make the summary more intelligible. 
SUMMARY OF REPLIES TO CIRCULAR NO. II.

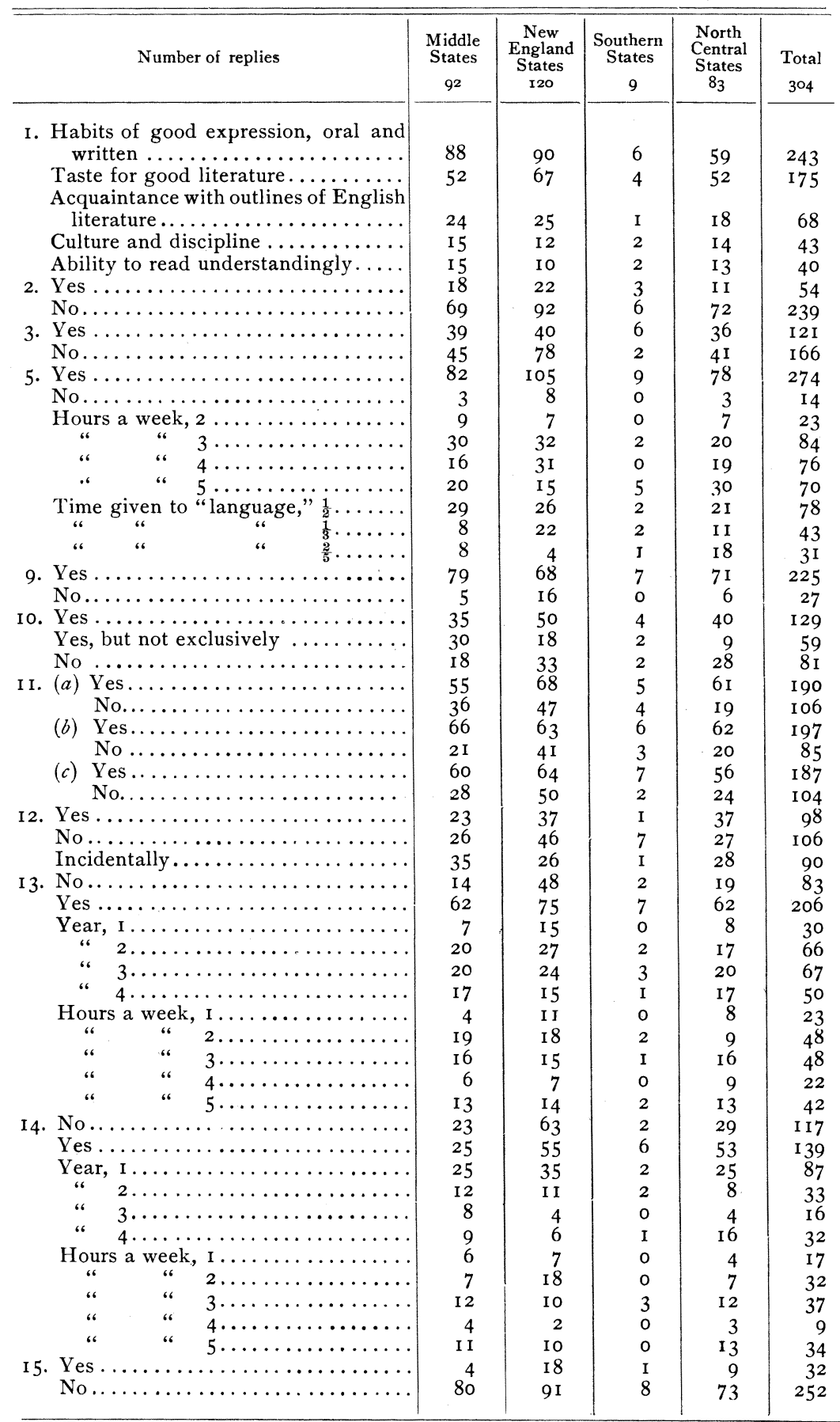

This content downloaded from 128.143.023.241 on August 11, 2016 05:30:16 AM

All use subject to University of Chicago Press Terms and Conditions (http://www.journals.uchicago.edu/t-and-c). 
There is much more in the returns than appears on the surface, but I can give, in the space at my disposal, only the briefest explanations. In general, I may say these returns support the conclusions arrived at by Mr. Farrand on the basis of the other circular. There is a widespread misunderstanding of the purpose of the college requirements, and a lack of uniformity in the methods of doing the work is clearly apparent. It is safe to say, moreover, that there is no recognized course of English beyond the study of the books prescribed for college entrance. The hostility of many schools to the present scheme is evidently based on the assumption that the college have marked out a course in English; some replies assume that the college requirements are intended to be a part of a systematic course in English and therefore require no special consideration. In either case it is difficult to tabulate the returns.

The one problem of prime importance is the determination, in outline at least, of the course of study. If the study of the books prescribed for college entrance is intended to be the only work in English in the secondary schools, even during the last year or two, the English Conference should say so. The result would be, judging from the temper of these replies, that most respectable high schools would promptly renounce the entire scheme. Fitting schools and the weaker high schools generally express implicit confidence in the wisdom of the higher powers, but evidences are not lacking of a rank skepticism in some quarters. I quote an answer to 7: "To do [as you request] would imply recognition of the required list as possessing some sort of scientific or necessary validity. But this list is purely fortuitous and adventitious, coming upon teachers $a b$ extra, nowhere rising to view in a purely philosophical study of a methodic in English. The list is the outcome of debate in a conclave, and aims to meet purely artificial conditions. To include it in a study of English procedures vitiates all conclusions."

On the contrary, if college entrance requirements are intended to be a part of a more extended course, it is imperative that "the higher powers" give some light on the pedagogical prin- 
ciples underlying the scheme in order that the course may be intelligently completed. "The laws of adolescent nature cannot with impunity be ignored." "The course in English should either have a rational theory and plan of its own, or it should illustrate and supplement the work in history, science, or language." A practical solution is suggested in the following extract from a personal letter:

The course outlined by this [college entrance] requirement is not the best possible course for pupils who are not going to pursue their studies further, but I do not think that it conflicts with such a course. Practically the case stands something like this: It is the general testimony that the present requirement can be adequately met in from two to three years with two or three recitations a week. This of course depends considerably on the previous training of the pupils, on their character, and on the amount of out-of-school study demanded. For classical pupils who have also had a satisfactory course in English language and literature previously this is a sufficient proportion of time to devote to English, and it is all that can be afforded under the present pressure of college requirements. For most other students, however, more time is necessary and desirable. With those who are going at once into the world I class those who intend to enter scientific and technical schools, because they have not had the humanistic training of the classical students, and because the courses of these schools contain so little of the literary element. These two classes of students, then, it seems to me, need decidedly more work in English than the others, and this extra work should include training in both language and literature. It is perfectly reasonable that these students should devote four or five periods a week to English instead of the two or three given by their classical brethren. It is entirely practicable, as is proved in more than one school, to carry all the pupils over the course called for by the college requirements, and to give the non-classical students such a supplementary course in composition, rhetoric, and literature as will meet their needs.

The answers to the fourth question show a widespread dissatisfaction with the English requirement even by those who accept it tentatively as the best possible at the present time. "It has no basic principle." "It tends to make the passing of examinations the end of scholarship." "There is no attempt to coördinate the study of English with other studies." "The pupil is set to writing about the writing of somebody else, instead of expressing his face-to-face contact with the facts of his own life." "It restricts the teacher too much." "It is too vague 
and uncertain." "Selections are made by specialists from the college viewpoint; we want material that is suggestive and inspiring to youth and suited to the learner's maturity and capacity." "The ideal course will be flexible enough to suit the peculiar needs of the pupils and the interests of the teacher."

The returns under the heads six, seven, and eight show conclusively not only that there is no generally recognized course of study in English but that few schools have any idea how to make one. If proof were needed that our best teachers of English are uncertain of themselves, these replies would furnish it. Uniformity in college entrance requirements has done much for the schools, but the end is not yet. The bladder holds the lad's nose above water, but it doesn't teach him to swim.

Perhaps the practical nature of the work as shown by the answers to the first question is responsible for much of the confusion. We are tolerably certain how best to "discipline the mind," but when it comes to the "formation of habits of expression" and the "inculcation of æsthetic taste," we find ourselves outside the beaten path. Undoubtedly the lack of agreement as to the ends to be attained has much to do with the confusion in methods. The five ideals above stated stand at the head of a list that ranges all the way from the "analysis of a typical English sentence" to the "familiarity with the greatest minds of all times." The entire problem would be nearer solution if there could be substantial unanimity concerning the objects to be attained. "And if the main objects of teaching English are attained, what matters it to the colleges, or to anyone outside of the schools, what list of books is studied?"

University OF Colorado,

James E. Russell

Boulder, Colo. 